


\title{
ADVERSE HEALTH EFFECT OF OCCUPATIONAL EXPOSURE TO CISPLATIN AMONG HEALTHCARE WORKERS
}

\author{
By \\ El Samra GH ${ }^{1}$, Gaballah $\mathrm{IM}^{1}$, Rashed $\mathrm{LA}^{2}$ and Shehata RA ${ }^{1}$ \\ ${ }^{1}$ Department of Occupational and Environmental Medicine, ${ }^{2}$ Department of Biochemistry, \\ Faculty of Medicine, Cairo University.
}

\begin{abstract}
Introduction: The Cis-diaminedichloroplatinum (Cisplatin) is one of the most efficient drugs used for treating many kinds of malignant tumors. The cytotoxicity of Cisplatin was not only affecting patients treated by Cisplatin but also can have an adverse effect among health care workers exposed to that drug during its preparation and/ or administration. Aim of work: To assess the deleterious effects of Cisplatin drug exposure on DNA among healthcare workers at the Oncology Department of Kasr Al Aini Hospital and estimation of early detection tools to be used as bioindicators for Cisplatin exposure. Materials and Methods: A case-control study was carried out on two groups, an exposed and a control group. The exposed group consisted of 32 nurses which represent the total number of nurses who are working in the chemotherapeutic section of the Oncology Department at Kasr Al Aini Hospital, Cairo University. The control group was composed of 37 nurses randomly selected from other departments of Kasr Al Aini Hospital and have never been exposed to antineoplastic drugs. Both groups were interviewed using specially designed questionnaire, clinical examination including general and systemic examination. Laboratory investigations were done including: blood picture, liver and kidney functions and estimation of Cisplatin DNA adduct blood levels. Results: The prevalence of menstrual disorders was significantly higher among the exposed compared to the non-exposed group (odds Ratio=8.3), there was statistically significantly higher rates of abortions outcomes among exposed female workers and wives of exposed male workers (odds ratio $=1.2$ ). Also the prevalence of frequent infections and hair loss was $37.5 \%$ and $68.8 \%$ respectively among the exposed
\end{abstract}


with no affection detected among the non-exposed group. Allergic symptoms were detected among $59.4 \%$ of the exposed population (Odds Ratio=12). As regard liver and kidney functions there is statistically significant increase in kidney functions (urea and creatinine) as well as aspartate aminotransferase (AST) levels of liver function among nurses exposed to Cisplatin. There was a highly statistically significant increase in Cisplatin DNA adducts level among exposed workers; that in-turn represented an indicator for serious DNA damage. Conclusion: Our study detected that occupational exposure to Cisplatin drug during preparation and administration is hazardous to the exposed workers even on using personal protective equipments.

Key words: Cisplatin, Cisplatin DNA adducts, Health effects and DNA damage.

\section{Introduction}

The Cis-diaminedichloroplatinum (Cisplatin) is one of the most efficient drugs used for treating many kinds of malignant tumors (Kovaltsova et al., 2007). The cytotoxicity of Cisplatin was not only affecting patients treated by Cisplatin but also can have an adverse effect among health care workers exposed to that drug during its preparation and/or administration (Valanis et al., 1997).

\section{Cisplatinhas been ranked byCAREX} Canada as a Group A (immediate high priority) for occupational settings, targeting people who may be exposed to the drug at work (i.e. nurses and pharmacists), rather than those who prescribed the drug for therapeutic use. Prioritization for pharmaceuticals was based on the carcinogenicity of the substance Cisplatin has been classified by IARC (1987) as Group 2A, probably carcinogenic to humans.

DNA is the major target for Cisplatin attack. It cross-links DNA producing intra and inter-strand links that modify the DNA structure, forming Cisplatin DNA adducts that inhibit DNA synthesis. The fate of these cells attacked by Cisplatin and forming Cisplatin DNA adducts is either showing programmed cell death (apoptosis) doing unregulated cell division which lead to the formation of a cancerous tumor or this Cisplatin induced DNA damage being repaired through many pathways using repairing proteins as Rad52 (Decatris, et al., 2004).

A cell that has accumulated a large amount of DNA adducts has no longer effectively repaired. DNA damage can enter one of three possible states: an irreversible state of dormancy, known 
as senescence, cell suicide known as apoptosis or programmed cell death or cause unregulated cell division, which can lead to the formation of a tumor that is cancerous (Spindler, 2005).

Cisplatin exposure was known to cause various organ damages and severe cumulative renal toxicity (O’Dwyer et al., 2000). It was proved to induce generation of mitochondrial reactive oxygen species thus triggering inflammatory response, cell death, as well as kidney dysfunction and nephropathy (Mukhopadhyay et al., 2011).

\section{Also Cisplatin affects blood} picture parameters, experimentally, Malarczyk and his colleagues, (2003) who examined the effect of Cisplatin exposure on healthy rats, discovered a significant increase in the leucocyte and erythrocyte counts after two weeks of exposure. However, recently Markovic and his coworkers, (2011) reported induced depletion of RBC and platelet numbers following prolonged Cisplatin treatment.

\section{Aim of work}

To assess the deleterious effects of
Cisplatin drug exposure on DNA among healthcare workers at the Oncology Department of Kasr Al Aini Hospital and estimation of early detection tools to be used as bioindicators for Cisplatin exposure.

\section{Materials and Methods}

- Study design: A case control study.

- Study population: The study is composed of an exposed and a control groups. The exposed group consisted of all nurses working at the chemotherapeutic section of the Oncology Department at Kasr Al Aini Hospital, Cairo University (32:25 females and 7 males). Their age ranges from 22 -60 years and with duration of employment ranging from 2-29 years. All nurses were using the Cisplatin drug through preparation and /or administration of the drug.

The control group was composed of 37 nurses randomly selected from other departments of Kasr Al Aini Hospital and have never been exposed to antineoplastic drugs. The group consisted of 35 females and 2 males with age ranges of 22-52years.This group 
matched the exposed group as regards gender, socioeconomic standard and special habits of medical importance.

\section{- Study Methods:}

The exposed and control groups were subjected to the following:

\section{- Questionnaire}

Specially designed questionnaire were used which included: medical, present, past and family histories with emphasis on menstrual and reproductive histories, occupational history including duration of employment and usage of protective equipments.

The exposed group was known to prepare and administer Cisplatin drug at the outpatient clinic room at the Oncology Department within the only biological safety cabinet. Sometimes they worked at the inpatient department where preparation and administration of the drug infusion took place in the absence of any specific ventilation system or biological safety cabinet. Working hours were between 8-12 hours/day.

\section{- Clinical examination:}

Clinical examination was done including general and systemic examination.

\section{- Laboratory investigations:}

A blood sample of $10 \mathrm{ml}$ wa s drawn from each subject. The samples were divided into smaller samples to suit the different laboratory investigations:

- A sample of $3 \mathrm{ml}$ of blood was delivered into a clean tube containing disodium ethylene diamine tetra acetate (EDTA) and mixed promptly for determination of hemoglobin percentage, total leucocytic count, red blood corpuscles and platelet counts using the Coulter counter model T-890 Coultronics, France.

- Another sample of $2 \mathrm{ml}$ of blood was allowed to clot then centrifuged for separation of serum and determination of liver functions by determination of serum aspartate aminotransferase and alanine aminotransferase enzymes. Kidney function tests, namely serum urea and creatinine were also investigated using the Hitashi (911) autoanalyzer. 
- $\quad$ The remaining $5 \mathrm{ml}$ sample was used for measuring parameters of DNA affection as Cisplatin DNA adducts level.

\section{Cisplatin DNA adducts assessment:}

Cisplatin DNA adduct was measured by ELISA kit supplied from Cell Biolabs. Inc.

Principle of assay: Cisplatin-DNA standards or unknown DNA samples are adsorbed onto a 96-well DNA high-binding plate. The CisplatinDNA adducts present in the sample or standard are probed with an AntiCisplatin Antibody, followed by an HRP Conjugated Secondary Antibody. The Cisplatin-DNA adduct content in an unknown sample is determined by comparing with a standard curve that is prepared from predetermined CisplatinDNA standards.

\section{Consent}

Authors declared that a verbal consent was taken from the studied groups and consent was taken from the Oncology Department before making the study. Confidentiality was maintained.

\section{Ethical approval}

The study protocol was approved by Occupational and Environmental Department Ethical Committee, Faculty of Medicine, Cairo University.

\section{Data management}

Data were coded and entered using statistical package SPSS version 15 . Data were summarized using numbers and percentage for qualitative variable, mean and standard deviation for quantitative variables.

Comparison between groups were done using Chi-square test for qualitative variables, independent sample t-test for normally distributed quantitative variables while nonparametric MannWhitney test was used for quantitative variables not normally distributed. p-value $\leq 0.05$ was considered statistically significant and $\leq 0.01$ was considered highly significant. 


\section{Results}

Table (1): Frequency distribution of the studied population according to medical history.

\begin{tabular}{|l|c|c|c|c|c|c|}
\hline \multirow{2}{*}{} & \multicolumn{2}{|c|}{$\begin{array}{c}\text { Exposed } \\
\text { No=32 }\end{array}$} & \multicolumn{2}{c|}{$\begin{array}{c}\text { Non-exposed } \\
\text { No =37 }\end{array}$} & \multirow{2}{*}{ Chi $^{2}$} & \multirow{2}{*}{ p-value } \\
\cline { 2 - 5 } & No & $\%$ & No & $\%$ & & \\
\hline Menstrual disorders & 6 & 24 & 1 & 2.8 & 9.33 & $\mathbf{0 . 0 0 4 * *}$ \\
\hline Frequent infections & 12 & 37.5 & 0 & 0 & 16.79 & $\mathbf{0 . 0 0 1 * *}$ \\
\hline Allergy & 19 & 59.4 & 4 & 10.5 & 18.2 & $\mathbf{0 . 0 0 1} * *$ \\
\hline Hair falling & 22 & 68.8 & 0 & 0 & 37.3 & $\mathbf{0 . 0 0 1} * *$ \\
\hline
\end{tabular}

**Highly statistically significant ( $\mathrm{p}$-value $<0.01$ )

Table (1) showed a highly statistically significant difference between both groups concerning frequency of infections (recurrent serious skin or respiratory infections twice/month); allergic manifestations (skin or respiratory allergy) (Odds Ratio=12) and massive hair falling. The results also showed statistically significant difference between exposed and non-exposed groups concerning menstrual disorders as menorrhagia, metrorrhagia, menometrorrhagia or menstrual irregularity (Odds Ratio=8.3).

Table (2): The frequency distribution of repeated abortions outcomes among the studied groups.

\begin{tabular}{|c|c|c|c|c|c|c|}
\hline \multirow{2}{*}{$\begin{array}{c}\text { Abortion } \\
\text { parameter }\end{array}$} & \multicolumn{2}{|c|}{$\begin{array}{c}\text { Exposed } \\
\text { No=32 }\end{array}$} & \multicolumn{2}{c|}{$\begin{array}{c}\text { Non-exposed } \\
\text { No=37 }\end{array}$} & \multirow{2}{*}{ Chi $^{2}$} & \multirow{2}{*}{ p-value } \\
\cline { 2 - 5 } & No & $\%$ & No & $\%$ & & \\
\hline No abortion & 23 & 71.9 & 36 & 93.3 & \multirow{2}{*}{9.35} & \multirow{2}{*}{$\mathbf{0 . 0 2 *}$} \\
\hline Abortion & 9 & 28.1 & 1 & 2.7 & \\
\hline
\end{tabular}

*Statistically significant (p-value $<0.05$ )

Table (2) showed a statistically significant difference between exposed and nonexposed groups as regard abortion where $9(28.1 \%)$ of female nurses and wives of exposed males gave a history of repeated abortions (Odds Ratio=1.2). 
Table (3): The mean values, ranges and standard deviations ( \pm SD) of liver and kidney functions among the studied groups.

\begin{tabular}{|c|c|c|c|c|c|}
\hline \multicolumn{2}{|c|}{ Laboratory investigations } & $\begin{array}{c}\text { Exposed } \\
\text { No }=32\end{array}$ & $\begin{array}{c}\text { Non-exposed } \\
\text { No }=37\end{array}$ & $\begin{array}{c}\text { Test of } \\
\text { significance }(t / z)\end{array}$ & p-value \\
\hline \multicolumn{6}{|c|}{ Kidney functions } \\
\hline \multirow{3}{*}{ Urea } & Mean & 27.7 & 23.9 & \multirow{3}{*}{2.1} & \multirow{3}{*}{$0.05 *$} \\
\hline & SD & \pm 7.39 & \pm 7.35 & & \\
\hline & Range & $12-41$ & $13-43$ & & \\
\hline \multirow{3}{*}{ Creatinine } & Mean & 0.81 & 0.67 & \multirow{3}{*}{3.5} & \multirow{3}{*}{$0.05 *$} \\
\hline & SD & \pm 0.19 & \pm 0.13 & & \\
\hline & Range & $0.5-1.6$ & $0.4-1.1$ & & \\
\hline \multicolumn{6}{|c|}{ Liver functions } \\
\hline \multirow{3}{*}{ ALT } & Mean & 19.7 & 16.2 & \multirow{3}{*}{-0.5} & \multirow{3}{*}{ N.S } \\
\hline & SD & \pm 11.8 & \pm 4.2 & & \\
\hline & Range & $8-65$ & $9-27$ & & \\
\hline \multirow{3}{*}{ AST } & Mean & 20.8 & 17.24 & \multirow{3}{*}{-2.0} & \multirow{3}{*}{$0.05 *$} \\
\hline & SD & \pm 11.8 & \pm 9.2 & & \\
\hline & Range & $10-75$ & $7-46$ & & \\
\hline
\end{tabular}

* Statistically significant (p-value $\leq 0.05$ ),

Urea $(\mathrm{mg} / \mathrm{dl})(\mathrm{N}=15-30 \mathrm{mg} / \mathrm{dl})$, $\operatorname{AST}(\mathrm{U} / \mathrm{L})(\mathrm{N}=8-40 \mathrm{U} / \mathrm{L})$,
N.S : Statistically non significant Creatinine $(\mathrm{mg} / \mathrm{dl})(\mathrm{N}=0.5-1.2 \mathrm{mg} / \mathrm{dl})$, $\operatorname{ALT}(\mathrm{U} / \mathrm{L})(\mathrm{N}=>40 \mathrm{U} / \mathrm{L})$

Table (3) showed a statistically significant difference between mean values of kidney functions and AST levels among the studied groups. 
Table (4): The mean values, ranges and standard deviations ( \pm SD) of blood picture parameters among the studied groups.

\begin{tabular}{|c|c|c|c|c|c|}
\hline \multicolumn{2}{|c|}{$\begin{array}{l}\text { Blood picture } \\
\text { parameters }\end{array}$} & \multirow{2}{*}{$\begin{array}{c}\begin{array}{c}\text { Exposed } \\
\text { No= 32 }\end{array} \\
13.1\end{array}$} & \multirow{2}{*}{$\begin{array}{c}\begin{array}{c}\text { Non-exposed } \\
\mathbf{N} \mathbf{0}=\mathbf{3 7}\end{array} \\
12.12\end{array}$} & \multirow[t]{2}{*}{$\begin{array}{c}\text { Test of } \\
\text { significance } \\
(t / z)\end{array}$} & \multirow[t]{2}{*}{$p$ value } \\
\hline \multirow{3}{*}{$\mathbf{H b}$} & Mean & & & & \\
\hline & SD & \pm 1.47 & \pm 1.29 & \multirow[t]{2}{*}{2.9} & \multirow[t]{2}{*}{$0.05^{*}$} \\
\hline & Range & $10.1-16.9$ & $9.8-16$ & & \\
\hline \multirow{3}{*}{ RBCs } & Mean & 4.62 & 4.48 & \multirow{3}{*}{1.5} & \multirow{3}{*}{ N.S } \\
\hline & SD & \pm 0.36 & \pm 0.38 & & \\
\hline & Range & $4.0-5.3$ & $3.7-5.6$ & & \\
\hline \multirow{3}{*}{ TLC } & Mean & 7.87 & 6.58 & \multirow{3}{*}{-2.5} & \multirow{3}{*}{ N.S } \\
\hline & SD & \pm 3.7 & \pm 1.69 & & \\
\hline & Range & $3.8-24.8$ & $3.4-9.8$ & & \\
\hline \multirow{3}{*}{ Platelets } & Mean & 257.2 & 257.7 & \multirow{3}{*}{-0.03} & \multirow{3}{*}{ N.S } \\
\hline & SD & \pm 80.5 & \pm 56.5 & & \\
\hline & Range & $136-498$ & $136-360$ & & \\
\hline
\end{tabular}

* Statistically significant (p-value $\leq 0.05)$,

N.S : Statistically non significant

$\mathrm{Hb}(\mathrm{g} / \mathrm{dl})(\mathrm{N}=11.6-18 \mathrm{gdl})$, RBC (10"6/cm)(3.8-5.5 10"6/cm ),

Platelets $(10 " 3 / \mathrm{cm})(150-40010 " 3 / \mathrm{cm})$, TLC (10"3/cm)(4-11 10"3/cm).

Table (4) showed non statistically significant difference between the exposed and non-exposed groups regarding means of the blood picture parameters except for hemoglobin $(\mathrm{Hb})$ values. 
Table (5): The means, ranges and standard deviations ( \pm SD) of genetic parameters (Cisplatin DNA adduct) among the studied groups.

\begin{tabular}{|c|c|c|c|c|c|}
\hline \multicolumn{2}{|c|}{ Genetic Parameters } & $\begin{array}{c}\text { Exposed } \\
\text { No=32 }\end{array}$ & $\begin{array}{c}\text { Non-exposed } \\
\text { No=37 }\end{array}$ & $\begin{array}{c}\text { Test of } \\
\text { significance } \\
(t / z)\end{array}$ & p-value \\
\hline \multirow{3}{*}{ DNA adduct } & Mean & 0.158 & 0.002 & & \multirow{2}{*}{$-7.2^{z}$} \\
\cline { 2 - 4 } & SD & \pm 0.14 & \pm 0.002 & $* *$ \\
\cline { 2 - 4 } & Range & $0.01-0.52$ & $0.001-0.01$ & & \\
\hline
\end{tabular}

**Highly statistically significant ( $\mathrm{p}$-value $<0.01$ )

Table (5) showed a highly statistically significant difference in the mean values of genetic parameters. The levels of DNA adducts was higher among exposed nurses compared to the non-exposed group.

Our work showed that only $34.4 \%$ of exposed nurses use personnel protective equipments (PPE) in the form of masks and gloves at work, while $43.8 \%$ use HEPA filter during the preparation of Cisplatin drug. Also this work showed that there was no statistically significant difference between exposed workers who were using personal protective equipments and those not using them as regards mean values of DNA adducts.

\section{Discussion}

Many authors reported the incidence of reproductive deficits as infertility, spontaneous abortions, fetal abnormalities, and menstrual-cycle abnormalities among females exposed to certain chemotherapeutic agents and the significant risk to their reproductive health (Valanis et al., 1997).In 1999, Valanis and his coworkers found that wives of exposed men have increased risk of adverse pregnancy outcomes similar to exposed females.

In our study, the prevalence of menstrual disorders was significantly higher among the exposed group compared to the non-exposed (odds Ratio=8.3). Among the exposed nurses, $24 \%$ suffered from menstrual disorders in the form of menorrhagia, metrorrhagia, menometrorrhagia or menstrual irregularity (Table 1). 
Also on analyzing the frequency of abortions among our studied groups to detect the effect of exposure on reproductive function, there was statistically significantly higher rates of abortions outcomes among exposed female workers and wives of exposed male workers (odds ratio $=1.2$ ). In fact, around $28.1 \%$ of the exposed population had one or more abortions while $2.7 \%$ only of the non-exposed group had abortus among their offspring as shown in Table 2. In agreement with our results, earlier case-control studies done by Selevan et al., 1985 and Merler et al., 1996; found a relationship between chemotherapeutic drugs exposure and spontaneous abortion. Other studies done by Rogers and Emmett, (1987) and Valanis and his coworkers, (1999) reported significantly higher proportion of adverse pregnancy outcomes in the form of recurrent abortion or still birth on exposure to anti neoplastic agents during preparation and administration of the drugs. Workplace exposure to these drugs has been associated with adverse reproductive outcomes among exposed female nurses and wives of exposed male nurses.
However, in contrast to our findings Hemminki and his colleagues, (1985) failed to prove the relation between exposure to chemotherapeutic drugs and spontaneous abortions among exposed nurses. Shortridge and colleagues (1995) reported no significantly increased risk of menstrual cycle dysfunction for any exposure to past handling, or current administration, or both preparation and administration of antineoplastic drugs (ANDs).

Other commonly reported clinical disorders with exposure to chemotherapeutic drugs (frequent infections, allergic symptoms and hair falling) showed statistically significant high prevalence among exposed than non-exposed workers (Table 1).

Krstev and his coworkers, (2003) reported that nurses exposed to antineoplastic drugs have significantly more symptoms than non-exposed nurses, mostly hair loss (Odd $\mathrm{R}=7.14$ ), skin rash and allergy (Odd $\mathrm{R}=4.70$ ). The frequency of symptoms revealed an exposure-effect relationship, with the highest number of symptoms among nurses exposed daily and lowest in nonexposed nurses $(\mathrm{p}<0.001)$. 
The current study showed a statistically significant increase in kidney functions (urea and creatinine) as well as aspartate aminotransferase (AST) levels of liver function among nurses exposed to Cisplatin compared to unexposed group (Table 3). Similar results were detected by Yao and his colleagues, (2007) who found that many patients exposed to Cisplatin had changes in glomerular filtration which could be identified by changes in serum creatinine.

Hepatocellular damage has also been reported among nurses working in oncology wards; the injury appeared to be related to intensity and duration of work exposure to chemotherapeutic drugs (Valanis et al., 1993). Earlier studies reported chronic irreversible liver fibrosis among nurses who prepared and administered antineoplastic drugs for more than 6 years without using protective equipments while other studies reported the non-elevation of liver enzymes among exposed nurses (Sotaniemi et al., 1983).

This study revealed no statistically significant difference between the mean values of blood parameters among exposed and non exposed groups except for the hemoglobin values (Table 4). Cisplatin- hemoglobin $(\mathrm{Hb})$ complexes were shown to be formed after Cisplatin exposure according to concentrations of Cisplatin and $\mathrm{Hb}$. Heame was released as noted side effect of platinum binding causing reduced $\mathrm{Hb}$. $\mathrm{Hb}$ and myoglobin might be easily affected by the stress imposed by Cisplatin (Bischin et al., 2011), thus explaining the significant difference of hemoglobin concentration between both groups.

Commonly, the nurses handle a number of different antineoplastic drugs in combination. Thus, the use of biomarkers to evaluate exposure to certain type of the various incorporated drugs was the aim. Villarini and his colleagues, (2011), observed that the majority of nurses are exposed to the most commonly handled antineoplastic drugs Cyclophosphamide and Cisplatin and that those two drugs are efficient producers of DNA-DNA inter-strand and intra-strand cross-links (DNA adducts). Accordingly, the mostly used Cisplatin DNA adducts was selected to study the amount of exposure as well as the effect of specifically Cisplatin 
exposure among nurses exposed to antineoplastic drugs.

The current work showed a highly statistically significant difference in the mean values of the levels of DNA adducts among exposed nurses compared to the non-exposed group (Table 5).

Similar to our results, Boffetta and his coworkers, 1998 suggested that DNA adducts formed by Cisplatin exposure might be predictive of Cisplatin levels in blood, and that the value of proteinbound Platinum in blood is in-turn predictive of DNA adducts values.

In our study, $34.4 \%$ of the exposed workers used personal protective equipments in the form of masks and gloves and $43.8 \%$ of them used HEPA filters during preparation. By observing the relation between usage of protective measures and the results of DNA adducts, we found no significant statistical difference in values of DNA adducts between nurses using protective equipments and those who did not. This is due to the irregular use of protective equipments even among nurses who used them especially during heavy work with large number of patients. Also the absence of HEPA filters in "in-patient department "where they also prepared the drugs; with improper maintenance of these devices.

Many surveys indicated that, nurses were less likely to use personal protective equipments as surgical latex gloves and impermeable disposable gowns, particularly for administering antineoplastic drugs or when contact with these drugs or body products (e.g., urine, feces, and vomitus) from patients receiving the drugs (Valanis et al., 1987; Valanis and Shortridge, 1987). In 1992, Valanis and his coworkers reported that skin contact with anti neoplastic drugs (ANDs) was associated with a significantly elevated risk of clinical symptoms characteristic to ANDs exposure, independent to the use of protective equipments.

In agreement with our findings, a study done by Izdes and his coworkers, (2009) on nurses handling the antineoplastic drugs, they detected significantly high levels of DNA damage among them in spite of the regular use of protective equipments in the form of gloves and masks while preparing the drug under vertical flow safety cabinet 
for the last two years before the study which mean that they were still at risk.

On the contrary to our work, Villarini and his colleagues, (2011) proved that the use of personal protective equipments as masks and/or gloves is associated with a statistically significant decrease in the extent of primary DNA damage.

\section{Conclusion and Recommendations}

Occupational exposure to cisplatin drug during preparation and administration is hazardous to the exposed workers even though they used personal protective equipments. The most common reported health hazards among exposed nurses are in the form of massive hair loss, frequent infection, allergic problems, menstrual disorders and frequent abortion. DNA damage caused by Cisplatin exposure could be early detected by blood level of Cisplatin DNA adducts which is a specific biopredictor to that damage.

Strict precautions should be implemented to all health care workers dealing with anti neoplastic drugs, including impervious chemo gowns, double-gloving, use of sophisticated “closed-system" devices and specialized ventilation hoods, face shields and respirators as well as clean rooms . Also heath education is mandatory to the hazardous health effects of these elements.

\section{Conflict of interest}

Authors have declared that no conflict of interests exists.

\section{References}

1. Bischin C, Lupan A, Taciuc V and SilaghiDumitrescu R (2011): Interactions between proteins and platinum containing anti-cancer drugs. Mini Rev Med Chem; 11: 214-24.

2. Boffetta P, Fichtinger-Schepman AM, Weiderpass E, van Dijk-Knijnenburg HC , Stoter G et al.,( 1998): Cisplatin-DNA adducts and protein-bound platinum in blood of testicular cancer patients. Anticancer Drugs; 9(2):125-9.

3. Decatris MP, Sundar S and O'Byrne KJ (2004): Platinum-based chemotherapy in metastatic breast cancer: current status. Cancer Treat Rev; 30:53-81.

4. Hemminki K, Kyyronen $\mathrm{P}$ and Lindbohm ML (1985): Spontaneous abortions and malformations in the offspring of nurses exposed to anaesthetic gases, cytostatic drugs, and other potential hazards in hospitals, based on registered information of outcome. J Epidem Comm Health ; 39:141-7.

5. Izdes S, Sardas S, Kadioglu E, Kaymak C and Ozcagli E (2009): Assessment of genotoxic damage in nurses occupationally exposed to anesthetic gases or antineoplastic drugs by the comet assay. J Occup Health; 51:283-286.

6. Kovaltsova SV, Chernenkov AY and Korolev VG (2007): Repair of Cisplatin-DNA adducts 
in mutants for genes controlling spontaneous and induced mutagenesis in Saccharomyces cerevisiae yeast .Russian Journal of Genetics; 43: 84-87.

7. Kintzel PE (2001): Anticancer drug-induced kidney disorders. Drug Saf; 24(1):19-38.

8. MalarczyK E , Kandefer-Szerszeń M and Jarosz-Wilkołazka A (2003): The Influence of Very Low Doses of Cisplatin on Tumor Cell Proliferation In Vitro and on Some Hematological and Enzymatic Parameters of Healthy Rats. Nonlinearity Biol Toxicol Med; 1(1): 123-137.

9. Marković SD, Zižić JB, Djačić DS, Obradović AD, Ćurčić MG, et al. (2011): Alteration of Oxidative Stress Parameters In Red Blood Cells Of Rats After Chronic In Vivo Treatment With Cisplatin and Selenium. Arch Biol Sci; 63 (4), 991-999.

10. Merler E, Villa S and Lucchini R (1996): Pathological effects due to antineoplastic drugs in workers engaged in their production, preparation or administration. Med Lav; 87(3):207-21.

11. Mukhopadhyay P,Horváth B,ZsengellérZ,Zielonka J , Tanchian G ,et al. (2011): Mitochondrial-targeted antioxidants represent a promising approach for prevention of Cisplatin-induced nephropathy. Free Radic Biol Med; 10: 1016.

12. O'Dwyer PJ, Stevenson JP and Johnson SW (2000): Clinical pharmacokinetics and administration of established platinum drugs .Drugs; 59: 19-27.

13. Rogers B and Emmett EA (1987): Handling antineoplastic agents: Urine mutagenicity in nurses. IMAGE Journal of Nursing Scholarship; 19:108-113.

14. Selevan SG, Lindbolm ML, Hornung RW and Hemminki K (1985): A study of occupational exposure to antineoplastic drugs and fetal loss in nurses. New England J Med; 313:1173-78.

15. Shortridge LA, Lemasters GK and Valanis B (1995): Menstrual cycles in nurses handling antineoplastic drugs. Cancer Nursing; 18: 439443.
16. Sotaniemi EA, Sutinen S and Arranto AJ (1983): Liver damage in nurses handling cytostatic agents. Acta Med Scand; 214:181-189.

17. Spindler SR (2005): Rapid and reversible induction of the longevity, anticancer and genomic effects of caloric restriction. Mech Ageing Dev; 126 (9): 960-6.

18. Valanis B and Shortridge L (1987): Selfprotective practices of nurses handling antineoplastic drugs. Oncology Nursing Forum; 14: 23-27.

19. Valanis B, Hertzberg V and Shortridge L (1987): Anti-neoplastic drugs: Handle with care. AAOHN Journal; 35: 487-492.

20. Valanis B, Vollmer W and Steele P (1999): Occupational exposure to antineoplastic agents: self reported miscarriage and stillbirths among nurses and pharmacists. J Occup Environ Med; 41:632-638.

21. Valanis B, Vollmer W, Labuhn K and Glass A (1997): Occupational exposure to antineoplastic agents and self-reported infertility among nurses and pharmacists. J Occup Environ Med; 39:574-580.

22. Valanis B, Vollmer WM, Labuhn K, Glass AG and Corelle C (1992): Antineoplastic drug handling protection after OSHA guidelines: Comparison by profession, handling activity, and work site. Journal of Occupational Medicine; 34: 149-155.

23. Valanis B, Vollmer WM and Glass AG (1993): Acute symptoms associated with antineoplastic drug handling among nurses. Cancer Nursing; 16: 288-295.

24. Voehringer DW, Mcconkey DJ, Mcdonnell TJ, Brisbay S and Meyn RE (1998): Bcl-2 expression causes redistribution of glutathione to the nucleus. Cell Biology. Proc Natl Acad Sci; 95: 2956-2960.

25. Yao X, Panichpsial K, Kurtzman $N$ and Kenneth N (2007): Cisplatin Nephrotoxicity. The American Journal of the Medical Science; 334 (2):115-125. 